\title{
The Irish Economic Crisis: The Expiry of a Development Model?
}

\section{Vanessa Boullet}

\section{Q OpenEdition \\ 1 Journals}

\section{Electronic version}

URL: http://journals.openedition.org/etudesirlandaises/4730

DOI: 10.4000/etudesirlandaises.4730

ISSN: 2259-8863

\section{Publisher}

Presses universitaires de Rennes

\section{Printed version}

Date of publication: 15 December 2015

Number of pages: $17-30$

ISBN: 978-2-7535-4366-9

ISSN: 0183-973X

\section{Electronic reference}

Vanessa Boullet, « The Irish Economic Crisis: The Expiry of a Development Model? », Études irlandaises [Online], 40-2 | 2015, Online since 15 December 2017, connection on 30 April 2019. URL : http:// journals.openedition.org/etudesirlandaises/4730; DOI : 10.4000/etudesirlandaises.4730 


\title{
The Irish Economic Crisis: The Expiry of a Development Model?
}

\author{
Vanessa Boullet
}

IDEA, Université de Lorraine

Abstract

This article studies the impact of the 2008 economic crisis on the Irish development model. The Republic of Ireland has developed its economy thanks to an FDI-led strategy. This strategy was very successful during the Celtic Tiger period in the 1990s and 2000s. Will the crisis put an end to Ireland's economic development? If Ireland manages to keep a low corporate tax rate, it appears that the country will be able to carry on with its development model. However, Ireland seems to have almost achieved its catching up with the EU core countries and it will be difficult to reach growth rates similar to those of the Celtic Tiger period.

Keywords: crisis, economic development, GNP, Celtic Tiger, FDI, European Union.

Résumé

L'Irlande a développé son économie à travers une politique d'ouverture économique et d'attraction des IDE dont le point d'orgue a été le Tigre celtique dans les années 1990 et 2000. Cet article étudie l'impact de la crise économique de 2008 sur le modèle de développement économique irlandais. Il apparaît que le modèle peut encore être valide, si l'Irlande parvient à préserver sa politique fiscale. Toutefois, il est peu probable que le pays puisse encore espérer des taux de croissance nettement plus élevés que le reste de l'UE car l'Irlande a fini son rattrapage économique.

Mots clés : crise, développement économique, PNB, tigre celtique, IDE, Union Européenne.

Ireland is one of the European countries that was hit hard by the 2008 crisis: the Irish State had to nationalize several banks and then had to be rescued by the Troika formed by the European Commission, the European Central Bank and the International Monetary Fund in 2010. It took only two years for the country to go nearly bankrupt after the fifteen years of prosperity under the Celtic Tiger period. Irish people had tobear the brunt of the reforms whereas they had thought that such times were over after being the euro area's fastest-growing country in terms of GNP per capita and having a net inflow of workers.

What is the reality of the crisis for Ireland? How did the country rise and fall? Was the crisis only the implosion of a real estate bubble or does it mark the end of 
Ireland's economic development? What does the future of Ireland look like, what could its new development model be and what should its ambition be?

\section{The Rise and Fall of the Celtic Tiger}

In September 2008, Ireland was the first country of the euro zone to enter recession ${ }^{1}$. It happened after fifteen years of exceptional growth and fast economic development, often called the Celtic Tiger. During that period, Ireland had been the euro areas fastest-growing and one of the richest countries in terms of GNP per capita ${ }^{2}$. The crisis occurred after decades of political and economic efforts to catch up with the EU member states.

\section{Ireland and Core EU GNP per capita (PPS) \\ Semi-logarithmic scale}

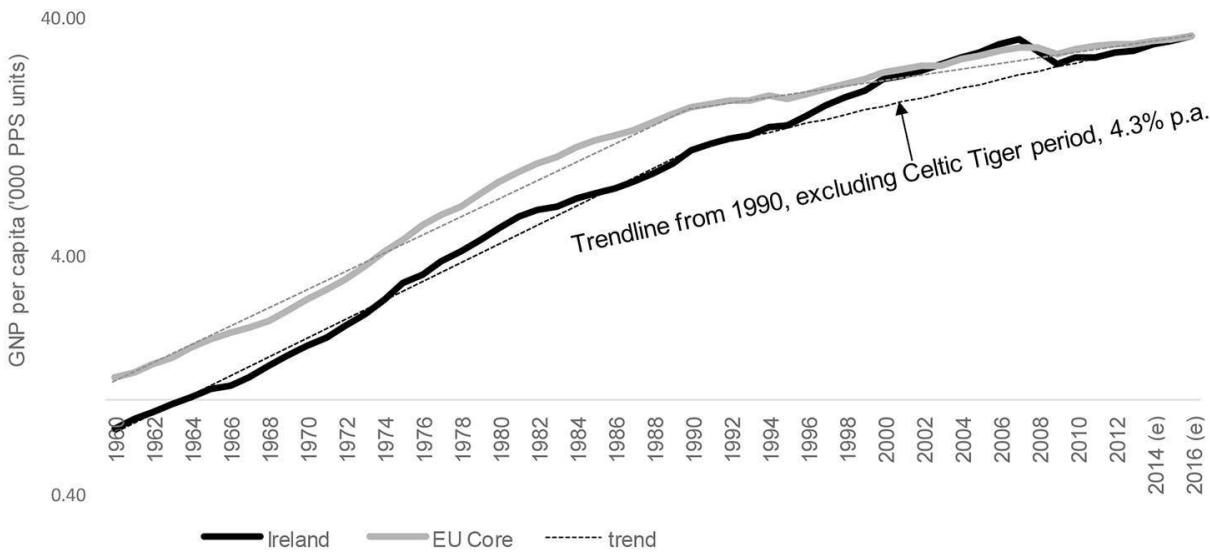

Figure 1: GNP per capita ${ }^{3}$ - Ireland and EU Core Countries (adjusted for inflation and at purchasing power parity) (calculations based on Eurostat: AMECO [Annual macro-economic database] of "Total population [National accounts] [NPTD]" and "Gross national income at current market prices per head of population [HVGNP])

1. OECD, "Quarterly Growth Rates of real GDP, change over previous quarter": - $2 \%$ for Q2 2008 and $-0,8 \%$ for Q3 2008, [http://stats.oecd.org/index.aspx?queryid=350\#], retrieved on 8 March 2015.

2. Eurostat, "Total population (National accounts) (NPTD)" and "Gross national income at current market prices per head of population (HVGNP), AMECO (Annual macro-economic database).

3. Traditionally GNP provides a better measure of economic activity in Ireland because of income flows to nonresidents, especially profits and dividends of foreign direct investment enterprises. For example, while in most EU countries the difference is just a couple of percentage points, in Ireland in 2007, GDP was as much as $23 \%$ higher than GNP. Even if we are aware that even GNP is now distorted because of the profit flows of redomiciled public limited companies (such as Accenture), in this article, GNP at constant price (adjusted for inflation and at purchasing power parity) is used to enable comparisons between EU countries. [http://econproph.com/2010/11/26/ gdp-vs-gnp/], [http://www._finfacts.ie/irishfinancenews/article_1025998.shtml], retrieved on 10 March 2015. 
The GNP per capita is adjusted for inflation and at purchasing power parity, which is usually considered as an acceptable proxy for the development of a country. The vertical scale of this graph is logarithmic, as a consequence a set of data with constant growth rate shows on this graph as a straight line.

From the 1960s to the 1980s, the Republic of Ireland lagged behind EU core countries (Austria, France, Belgium, the Netherlands, Germany, Luxembourg, Denmark, Finland, Sweden and the UK) as shown in graph $1^{4}$. Slowly but steadily, the policies implemented since $1958^{5}$ enabled Ireland's GNP per capita to grow, with a clear acceleration around 1994, to the point of catching up with the other EU member states in the early 2000s and exceeding the EU's core countries in 2003 in terms of GNP per capita at constant prices. Between 2001 and 2007, GNP growth rates averaged $5.6 \%{ }^{6}$. At the end of the Celtic Tiger period, in 2007, only three countries of the European Union (Luxembourg, Sweden and the Netherlands) had a GNP per capita higher than Ireland's ${ }^{7}$. Ireland also managed to reduce its public debt from $110 \%$ of economic output in 1987 to $24 \%$ in 2007, then the second-lowest in the euro zone ${ }^{8}$. Finally in 2007, at the end of the Celtic Tiger period, the general government balance was marginally positive?

In a nutshell, within four or five decades, Ireland was transformed from a poor country into a highly successful economy. Its development model was praised, studied and copied by many emerging economies like the eight countries of Central Europe which joined the EU in $2004^{10}$. After this period of fast growth, in the mid-2000s, several world financial institutions forecast a soft landing for the Celtic Tiger within 5 to 10 years:

The view of the [Central Bank of Ireland] was that Irish economic growth would continue, albeit at a lower rate, and that, despite the incipient downturn in the property sector, there would be a soft landing for the Irish economy. This benign assessment mirrored those made by the International Monetary Fund (IMF), the European Union (EU), and the

4. Graph 1 is based on the 28 countries of the EU. The author compares the Irish situation with EU core countries (Austria, France, Belgium, the Netherlands, Germany, Luxembourg, Denmark, Finland, Sweden and the UK). Calculations based on Eurostat, AMECO, op. cit.

5. In the late 1950 s and 1960s, T.K. Whitaker and S. Lemass opened Ireland to the world through 3 schemes: trade barriers were removed, FDI was attracted, the EEC membership was secured, and investments in education were made. Vanessa Boullet, La planification en Irlande (1958-1972), méthodologies et mythologie de la modernisation économique, 2008, Université de Paris Ouest-Nanterre-La Défense, Thèse.

6. OECD, "Quarterly Growth Rates of real GDP, change over previous quarter", op. cit.

7. Calculations based on Eurostat, AMECO, op.cit.

8. Arthur Beesley, "National debt and its servicing still weigh heavily on State", The Irish Times, 16 November 2014.

9. Eurostat, "General government deficit and surplus - annual data". [http://ec.europa.eu/eurostat/tgm/table.do?tab= table Splugin=1 \&language=en Śpcode=teina200], retrieved on 8 March 2015.

10. "The Irish economy, a model of success", The Economist, 14 October 2004. 
Organisation for Economic Co-operation and Development (OECD) around the same time ${ }^{11}$.

Not all economists did agree with the point of view of such worldwide financial institutions. In 2007, Morgan Kelly wrote:

The expected fall in average real house prices is in the range 40 to 60 per cent, over a period of around 8 years. [...] Given the unusual reliance of the Irish economy on building houses, the effects of any such fall on national income may be somewhat larger than that experienced at the end of other housing bubbles ${ }^{12}$.

Indeed, the Republic of Ireland suffered a rather hard landing, sooner than expected. On September 15, 2008, the financial services firm Lehman Brothers collapsed. The Irish housing bubble burst shortly afterwards, triggering a cascade of events: the Irish banking system was endangered to the point that the Irish government had to announce an unconditional guarantee of $€ 440$ billion for most liabilities of Ireland's seven major banks; unemployment more than tripled to $14.4 \%$ in $2011^{13}$; the Irish GNP per capita shrank by almost $10 \%$ in 2008 and by another $12 \%$ in $2009^{14}$. The State's balance sheet was also hit hard: tax revenue receded as, according to Antoin E. Murphy, "government revenue had become hugely over-dependent on taxes related to property transactions - including stamp duty, capital gains tax, VAT, and direct taxes levied on the property sector ${ }^{15}$ ". The public debt of the Republic, which stood at $24 \%$ in 2007 , steadily rose during the crisis to $123 \%$ of the $\mathrm{GDP}^{16}$. On November 21, 2010, Ireland petitioned the EU for a bailout. A financial rescue plan of $€ 90$ billion, almost $60 \%$ of Ireland's 2010 GDP, in the form of a three-year loan, was negotiated with the European Commission, the European Central Bank and the International Monetary Fund (the "Troika").

Between 2008 and 2010, nobody in Ireland was untouched by the crisis. Irish families had to make many sacrifices as public services budgets were cut down: "Over the course of the adjustment period, the combined effects of the cuts in

11. Antoin E. Murphy, "The Fall of the Celtic Tiger, Ireland and the Euro Debt Crisis", Presentation of the authors' book, p. 3. [https://www.qub.ac.uk/home/ResearchandEnterprise/BusinessNetworks/FileStorel Filetoupload,442419,en.pdf], retrieved on 08/03/2015.

12. Morgan Kelly, "On the likely extent of falls in Irish house prices", Quaterly Economic Commentary, Special Article, July 2007, Dublin Economic and Social Research Institute, p. 53.

13. Unemployment rose from $4.6 \%$ to $6.1 \%$ in 2007 , to $11.8 \%$ in 2009 , to $13.7 \%$ in 2010 and $15.1 \%$ in 2012. CSO, Seasonally Adjusted Standardised Unemployment Rates, [http://www.cso.ielen/statistics/labourmarket/ principalstatistics/seasonallyadjustedstandardisedunemploymentratessur/], retrieved on 8 March 2015.

14. Calculations based on Eurostat, AMECO, op. cit.

15. Antoin E. Murphy, op. cit., p. 6.

16. Eurostat, "General government gross debt - annual data, [http://ec.europa.euleurostat/tgm/table.do?tab=tabledrin it=1 \&language $=$ en Sopcode=teina225 Óplugin=1], retrieved on 08 March 2015. 
welfare rates and increases in taxes meant that most people experienced a fall in income of around 10 per cent ${ }^{17}$." Moreover, net emigration which had stopped in 1995 with the rise of the Celtic Tiger started increasing again on a very sizeable scale in 2010, (the net migration balance amounting to $-27,500$ people ${ }^{18}$ ). Thus, Manfred Gärtner, Björn Griesbach, and Giulia Mennillo concluded that "the achievements of 20 years of economic reforms, budgetary discipline and consensus under the Celtic Tiger had been lost in as little as four years ${ }^{19}$. Finally, the self-confidence that Ireland had during the Celtic Tiger was all but gone:

All of that confidence has ebbed away. Ireland today seems a vulnerable and anxious place, its uncertain future tied to borrowing and bailouts, the sheer size of which set the head reeling. Suddenly, too, the spectre of the old, pre-Celtic Tiger Ireland looms large, a place defined not by hope and optimism but by high unemployment, poverty and mass emigration $^{20}$.

Since 2012, however, Ireland has been recovering. The GNP per capita has risen again ${ }^{21}$ and Ireland is back, close to the EU15 average (graph 1). In June 2015, unemployment was still high at $9.7 \%{ }^{22}$ but was nevertheless below the euro-zone average $\left(11.1 \%{ }^{23}\right)$, tax revenues were rising. More importantly the 2014 budget deficit fell below $4 \%$ of GDP ${ }^{24}$.

So the crisis sent Ireland backwards, but does not seem to have wiped out the progress made in recent decades. The trendline on Graph 1 shows that to a large extent the crisis "only" cancelled out the additional growth that happened after 1994, that is to say above the trendline. So was the crisis that Ireland went through only the correction of some excesses of the Celtic Tiger or was it more fundamentally the end of Ireland's economic development model? What kind of crisis was it?

17. John FitzGerald, "Where Did the €30bn in Cuts Go?”, The Irish Times, 17 February 2015.

18. CSO, Annual Population Change (Persons in April) (Thousand) by Component and Year, [http://www.cso.ie/ multiquicktables/quickTables. aspx?id=pea15], retrieved on 8 March 2015.

19. Manfred Gärtner, Björn Griesbach, and Giulia Mennillo, "The Near-death Experience of the Celtic Tiger: A Model-driven Narrative from the European Sovereign Debt Crisis", Discussion Paper no. 2013-21, Department of Economics, U of St. Gallen, 2013, p. 13.

20. Sean O'Hagan, “Enough is Enough: How to Build a New Republic by Fintan O’Toole - review”, The Guardian, 21 November 2010.

21. GNP per capita: $+0.5 \%$ in $2011,+3.6 \%$ in $2012,+2.8 \%$ in $2013,+5.2 \%$ in 2014 . Calculations based on Eurostat, AMECO, op. cit.

22. CSO, "Live Register, June 2015", [http://www.cso.ie/en/releasesandpublications/er/mue/monthlyunemploymentjune2015/] (retrieved on 25 July 2015).

23. Eurostat, "Unemployment statistics", [http://ec.europa.eu/eurostat/statistics-explained/index.php/Unemployment_ statistics], retrieved on 25 July 2015.

24. Richard Barley, "Ireland's Economy Returns to the Core of Europe", The Wall Street Journal, 11 September 2014. 


\section{圈 The end of Ireland's economic development model?}

The starting point of the crisis is often identified as the bursting out of the real estate bubble. However, it was only a trigger and the crisis was deeper and multi-faceted: a housing bubble by itself would hardly cause the near-bankruptcy of several banks, a sharp economic contraction, rising unemployment, a reduction of the standard of living of Irish people and a ballooning state debt which led to austerity measures that aggravated the crisis for a while.

Indeed, excesses in Ireland under the Celtic Tiger were not all directly linked to the real estate sector. The banking sector also participated as it fuelled the bubble: private sector credit more than doubled over the bubble years ${ }^{25}$. The problem is that the banking sector financed the boom by borrowing amounts abroad above their capacity to pay them back. Early warnings of an impending bubble were ignored ${ }^{26}$. Therefore, Ireland was rapidly contaminated by the US subprime crisis. Beyond the correction of excesses, exemplified by the real estate bubble, did the crisis reveal a fundamental weakness in Ireland's development model?

Since 1958, Ireland has mainly implemented an export-led development strategy backed by Foreign Direct Investment (FDI). The Irish state has been very successful in attracting FDI thanks to a combination of factors. Some factors are the basic enablers of FDI: the Irish economy is open to international trade, its infrastructure is of a reasonable quality, it offers opportunities to export to an attractive region - the European Union. Additionally, Ireland has leveraged four specific factors: its overall low costs, its skilled workforce, a favourable tax structure and the critical mass it has reached in some industries. As Ireland is recovering from the crisis, are these four specific factors still a competitive advantage for Ireland?

Before becoming the Celtic Tiger, Ireland always had sold itself as a low-cost country. After the recession of the 1980s, Irish labour costs were low compared to other EU countries, all the more since the government had implemented social partnership agreements between business leaders, labour, and the government to keep wages under control. However, with the Celtic Tiger, employees felt they deserved a larger share of the new wealth and wages rose significantly ${ }^{27}$. How can a country claim on the one hand to be a low-cost country and on the other hand

25. John FitzGerald and Ide Kearney (eds.), Medium-Term Review, 2013-2020, Dublin, ESRI, p. 6.

26. The banking industry did not pay attention to "conventional early warning indicator of domestic imbalances, the current account of the balance of payments [because of the] membership of monetary union". Ibid., p. 6.

27. Sarah Voitchovsky, Bertrand Maitre \& Brian Nolan, "Wage Inequality in Ireland's 'Celtic Tiger' Boom", The Economic and Social Review, Vol. 43, No. 1, Spring, 2012, p. 103. 
to have one of the highest GNPs per capita of the EU, as it was during the early 2000s?

Business costs increased considerably during the Celtic Tiger period to the point that Ireland was no longer perceived as a low-cost country: some multinationals even decided to relocate their manufacturing facilities to cheaper countries (Dell for example transferred PC assembly from Limerick to its new plant in Łódź, Poland in 2008/09; Aviva Hibernian relocated its back office and support services to India in 2008). During the crisis, overall Irish labour costs stagnated ${ }^{28}$ and commercial property values collapsed by up to $67 \%$ from the peak years in 2006- $07^{29}$. Thanks to the crisis, Ireland now compares favourably with other EU core countries. However, there are now 28 member states within the EU, and compared to EU Eastern countries, Ireland is expensive, even after the crisis.

Since the mid-1960s, the Irish government has been investing in education, understanding the need for a skilled and trained workforce to develop its economy and attract FDI. Ireland has emphasized the quality of its education system and especially its third-level education for years. The problem is that with the crisis, Ireland suffered a brain-drain of its skilled workforce as young people emigrated to find jobs worldwide ${ }^{30}$. Senior research and policy officer with the National Youth Council of Ireland Marie-Claire McAleer said:

Many of [Irish emigrants] are highly skilled and educated. This represents a brain drain and will inhibit our economic recovery. We need a pool of well-educated people to attract investment and stimulate and sustain economic growth ${ }^{31}$.

The Irish low corporate tax rate is often cited as a key success factor for attracting FDI in Ireland ${ }^{32}$. Since 1958, Ireland has implemented a generous fiscal policy. It was initially a zero corporate profits tax on manufactured exports. In 1980 , the zero rate was replaced by a flat rate of $10 \%$ on all manufacturing. Then in 2003 as a consequence of many pressures from the European Union, it rose to $12.5 \%$. However as all the EU member states compete to attract the same FDI

28. Between 2001 and 2008, labour costs rose on average by $4.8 \%$. During the crisis, Irish labour costs rose by 0.01\%. Eurostat, "Labour cost index, nominal value - annual data", [http://ec.europa.eu/eurostat/web/labourmarket/labour-costs/database], retrieved on 9 March 2015.

29. Goodbody, "Irish Property", [http://static.rasset.ieldocuments/business/goodbody-property-market.pdf], retrieved on 9 March 2015.

30. Helen O'Toole told a vivid example in the article "I turned into my mother, lying on their beds, sobbing", The Irish Times, 6 February 2015.

31. Ciarra Kenny, "Emigration of Irish nationals falls 20\% in year to April", The Irish Times, 26 August 2014.

32. Anne Anderson quoted in "Investment in Ireland: A Success Story", National Foreign Trade Council, 23 Sep-

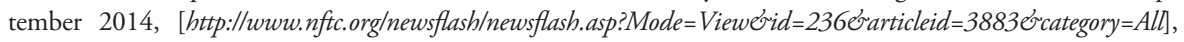
retrieved on 10 October 2014. 
( $R \& D$ and high-tech FDI), Ireland's particularly favourable rate is an increasing bone of contention.

However, Ireland's low tax rate is not the part of the Irish fiscal system that is most challenged. Ireland is considered as a tax haven by some countries, like the United States ${ }^{33}$ because after the tech bubble burst in 2000, Ireland seems to have moved from a high-tech to a tax avoidance country in some companies' views. Some American firms have indeed set up branches in Ireland to reduce their tax bills. The tax avoidance system enables companies to send their profits to zerotax island havens like Grand Cayman or Bermuda through Ireland. Those Irish subsidiaries sometimes have virtually no employee and pay no income tax. This mechanism was called the "double Irish" corporate tax mechanism ${ }^{34}$. Ireland was forced by the OECD ${ }^{35}$, the EU and the US to put an end to it. In October 2014, Minister for Finance Michael Noonan introduced a new regime for corporate taxation with the abolition of the corporate tax mechanism that enabled the "double Irish" scheme ${ }^{36}$. In the new tax code, multinational firms registered in Ireland will have to be tax resident. The old taxation scheme will be closed to new entrants from 2015 and phased out for existing multinational firms by $2020^{37}$. To carry on attracting inward investment, the Irish government announced the introduction of different measures. The most important (and controversial) one is the establishment in 2016 of a new incentive, on top of R\&D tax break schemes, to encourage companies to locate research in Ireland by offering them a lower tax rate on profits derived from intellectual property activity. It would be similar to the UK patent box, introduced in 2013 and restricted in 2015 following tax scrutiny by the EU and the $\mathrm{OECD}^{38}$. Will it be another Irish tax loophole? So far, Irish leaders have commented that tax policy was Ireland's "sovereign right ${ }^{39}$ ".

33. In a 2013 report, "An Analysis of Where American Companies Report Profits: Indications of Profit Shifting”, the US Congressional Research Service analysed two sets of countries, five traditional economies (Australia, Canada, Germany, Mexico and the United Kingdom) and five countries commonly identified as being "tax preferred" or "tax haven" countries (Bermuda, Ireland, Luxembourg, the Netherlands, and Switzerland)".

34. Profit-shifting: the United States has one of the world's highest corporate tax rate (over 30\%). In order to avoid paying high taxes, companies report their profits in low-tax or no-tax jurisdictions instead of the United States. Companies will only pay American profit taxes if they repatriate their profits to the United States.

35. The Centre for Tax Policy and Administration has a unit working on "Base Erosion and Profit Shifting" (BEPS).

36. Michael Noonan, "Finance Minister Michael Noonan - Budget 2015 speech", Merrion Street Website, [http:// www.merrionstreet.ielindex.php/2014/10/finance-minister-michael-noonan-budget-2015-speech/], retrieved on 18 October 2014.

37. Suzanne Lynch, "Abolition of 'double-Irish' in Budget 2015 welcomed by EU tax commissioner", The Irish Times, 14 October 2014.

38. To avoid transfer pricing, the UK patent box relief would be restricted "to profits generated from IP that was initially developed in the UK". "A fresh start for the UK's patent box scheme", LexisNexis PSL tax, 28 November 2014, [http://www.mmp-tax.co.uk/pdfs/A_fresh_start_for_UK_patent_box_28112014.pdf], retrieved 26 July 2015.

39. Anne Anderson quoted in "Investment in Ireland: A Success Story", op. cit. 
However, the recent publicity around the cases of profit-shifting of high-technology firms such as Apple, Google, Facebook or LinkedIn and cases of "corporate inversions ${ }^{40}$ " increased the intensity at which European and American policy makers put pressure on the Irish and Dutch governments.

Finally, over the years, Ireland has built strong innovative industrial clusters, based on the theory of Michael Porter ${ }^{41}$, in the main FDI sectors: ICT / software, pharmaceutical / chemical and international financial services. Industrial clusters in Ireland date back to the Culliton Report in $1992^{42}$, which recommended the promotion of industrial clusters focused on niches of national competitive advantage. Since then, the IDA (the Irish agency in charge of attracting FDI) and Enterprise Ireland have worked to target sectors that are "experiencing international growth and that are thought to provide a good fit for Ireland's resources and development aims ${ }^{43}$. . Now, the IDA tries to sell Ireland as an RDI location (Research, Development $\&$ Innovation) with the aim of creating new clusters:

IDA believes a range of sectors present opportunities for Ireland over the period of the strategy, including: internet of things, big data, security biometrics, smart ageing, portable services and financial technology $y^{44}$.

To that end, on top of the abovementioned intellectual property tax scheme, the Irish State now offers a 25\% R\&D tax credit to "encourage companies to undertake new or additional RDI activity in Ireland ${ }^{45}$ ".

Thus, the crisis may have slightly improved Ireland's cost position, but the Republic is no longer a low-cost country. Its workforce is still highly educated, but the demon of its past, emigration, is back. The tax system is still very attractive but beleaguered and will most likely lose at least part of its appeal. Ireland has become a mature FDI country: it has lost some of its edge, but it has gained a track record, tangible in its industrial clusters which can reassure investors.

Since some pillars of the Irish economic development model have all but disappeared, what does Ireland's economic future look like? Will the Irish growth

40. The US firm buys a foreign firm (avoiding paying tax on repatriated benefits since they were spent to buy the foreign company) and transfers its headquarters to the recently bought company, thus avoiding paying US tax in the future. Accenture moved its HQ in 2009 or Endo in 2014. "Tax avoidance: the Irish inversion", The Financial Times, 29 April 2014.

41. Michael Porter, The Competitive Advantage of Nations, New York, Free Press, 1990.

42. The Industrial Policy Review Group, A Time for Change: Industrial Policy for the 1990s, Dublin, Stationery Office), 1992.

43. Frank Barry, "Foreign Direct Investment, Industrial Policy and the Emergence of an Irish Indigenous Software Cluster", p. 4. [http://www.tcd.ielbusiness/stafffbarry/papers/FDI,\%20Industrial\%20Policy\%20and\%20the\%20 Emergence\%20of\%20an\%20Irish\%20Indigenous\%20Software\%20Cluster.pdff, retrieved on 11 March 2015.

44. IDA Ireland, [http://www.idaireland.com/en/newsroom/ida-strategy/index.xml], retrieved on 11 March 2015.

45. IDA Ireland, Research, Development and Innovation, [http://www.idaireland.com/en/business-in-ireland/activities/research-development-and-innovation/], retrieved on 11 March 2015. 
rate simply equal the other EU mature economies' or can it slightly or significantly outperform that of the EU core countries? If its current model has lost its edge, can Ireland invent a new development model?

\section{Will the Irish Tiger roar again?}

The first question is whether Ireland still has significant potential to raise its GNP per capita? By 2013, Ireland had nearly caught up once more with some EU core countries ${ }^{46}$ (such as France or the UK). Still, several EU core member states had a better position. First, Luxembourg stood on its own with a GNP per capita (in thousands of units of purchasing power standard) of 43 in 2013 (compared with 29.4 for Ireland 31.3 for core countries on average). Luxembourg's favourable position was possibly related to its fiscal policies that some compared to those of a tax haven. Then, there was a group of countries with a GNP per capita approximately $10 \%$ higher than the one of Ireland's: Sweden, the Netherlands, Austria, Denmark, and Germany. So, unless Ireland is ready to embark further on the risky path of a tax haven country, it could possibly expect to gain another $10 \%$ of GNP per capita.

The ESRI (Economic and Social Research Institute) clearly states that Ireland's future is tightly linked with the one of the European Union. How can a country whose economic future depends on the EU do more than mere catching up?

The pillars of Ireland's economic development paradigm are based on Ireland's competitive advantages over its neighbours to attract FDI. The cost of labour is - or used to be - one or Ireland's competitive advantage, however in the 20002013 period, average annual wages in Ireland grew faster than in other European countries (they exceeded Belgium's and the Netherlands' and in 2013 Luxembourg was only $18 \%$ more expensive than Ireland while it was $32 \%$ in 2000) ${ }^{47}$ It may be only a matter of time before the competitive advantages of lower wages and costs disappear or worse, become a liability. It would also be difficult for Ireland to claim that it has a more qualified workforce than other EU core countries. Ireland can only insist on the English language or the investment made on third-level education over the years. Finally, Ireland has developed industrial and financial clusters, but even if the ICT or pharma-chem clusters are well-established in Ireland, all the EU countries are trying to create clusters in key FDI sectors, and it will be difficult for Ireland to keep its primacy. This only leaves Ireland with its tax advantage. This policy is very effective $(12.5 \%$ in Ireland

46. 31.1 for Ireland vs 32.1 for core countries. Eurostat, AMECO, op. cit.

47. OECD.Stats, "Average annual wages 2000-2013" [http://stats.oecd.org/Index.aspx?DataSetCode=AV_AN_ WAGE], retrieved on 26 July 2015. 
versus $20 \%$ in the UK for example), but the Irish corporate tax rate and its tax credits are increasingly challenged by the EU and the USA.

The comparison with more recent EU member states (in particular in the Eastern part of Europe) also has to be qualified. Ireland is more expensive but could possibly claim a more qualified workforce and a better track record. The main differentiator is again the tax policy but having copied the Irish development model, Eastern EU countries are just above the Irish corporate tax rate with rates ranging from $15 \%$ to $25 \%$ except for Bulgaria with $10 \%{ }^{48}$. If Ireland were forced to raise its corporate tax rate to $15 \%$, it would reach the same level as Latvia, Lithuania, and Romania (16\%). So, Eastern countries appear to be weaker rivals than EU core countries. Compared to Eastern countries, high-tech companies will be reassured by Ireland's qualified workforce (including the English language skills, since many high-tech firms are based in the United States), its track record and - in a sector with potentially sky-high and intellectual property-based profit margins - its tax system.

Nevertheless, attracting inward FDI into Europe appears to be more and more competitive and difficult. It seems unlikely that Ireland would be able to carry on attracting the lion's share of FDI destined to Europe during the next decade. It is true that during the 2009-2013 period Ireland received more FDI compared to the previous period (2004-2008). But it was exactly the same situation for Germany, the UK, the Netherlands, and also Spain and Italy.

Thus, it seems that Ireland is no longer a fast-growing country. It now has many characteristics of a mature country. The Republic of Ireland could possibly try to play this game, with an Irish twist that would give it some extra growth compared to the rest of EU core countries. In this case, the main extra ingredient would be its tax policy, combined of course with Ireland's other competitive advantages: the language, the close relationship with the US and the EU, and the industrial clusters on IT \& chemical products. This is summarized - possibly in an optimistic way - by Ireland's Ambassador to the United States A. Anderson who declared:

After the difficulties we experienced in the aftermath of 2008, our economy is back on its feet again - with buoyant foreign investment, rising exports, very healthy tourism, and reducing (even if still much too high) unemployment. The mix we provide - highly skilled workforce, very competitive corporate tax rate of $12.5 \%$, an English speaking

48. List on [http://www.kpmg.com/global/en/services/tax/tax-tools-and-resources/pages/corporate-tax-rates-table.aspx], retrieved on 11 March 2015. 
gateway to the European Union - continues to demonstrate its attractiveness $^{49}$.

How does this translate into GNP projections? The Medium Term Review 2013-2020 of the Economic and Social Research Institute considered three economic scenarios for Ireland. Even more interesting than the scenarios themselves is the fact that the ESRI clearly states that Ireland's future is tightly linked with the one of the European Union. In the "Recovery" scenario of the ESRI, the EU15 growth rate is to return to about 2\% between 2015 and 2020 and Ireland will manage to almost double this growth rate over the same period if it addresses domestic issues such as the solidity of Irish banks, thus enabling Ireland to fully benefit from improved export outlets. In the "delayed recovery" scenario, the EU 15 growth rate is also at about $2 \%$, but Ireland will not manage to fix its domestic issues. In the third scenario entitled "stagnation", the EU 15 growth rate will remain lower than $0.5 \%$ but having addressed its domestic issues, Ireland will still reach $1.4 \%{ }^{50}$. Interestingly, the ESRI does not dare consider the scenario where the EU 15 growth rate will remain slow and Ireland will not manage to fix its financial sector.

Projecting these figures on graph 1 , with some simplification hypotheses ${ }^{51}$, it seems that the ESRI takes the catching up of Ireland with EU core countries as a key hypothesis. We can see these scenarios would lead to two possible outcomes by 2020 on graph 2. Outcome "A" corresponds to the "Recovery" and "Delayed recovery" scenarios of the ESRI: in this case, Ireland will catch up with the EU core countries and even outperform them. In outcome "B", corresponding to the "Stagnation" scenario, Ireland and the EU core countries share the same dire future.

It is also interesting to note that both "recovery" scenarios (outcome A) more or less follow the trendline of ca. 4.3\% growth per annum (from 1990 on graph 1) that Ireland may have followed without the excesses of the Celtic Tiger,

49. Anne Anderson, "Ireland, Europe and the US: A Road to Recovery and Renewed Partnership", 29 May 2014. [https://www.dfa.ie/irish-embassy/usa/news-and-events/2014/ireland-europe-and-the-us/], retrieved on 11March 2015.

50. With the slight increase in the population (+16,500 in April 2014 and the population is forecast to grow). CSO, "GNP per capita will increase a bit less". [http://www.cso.ielen/releasesandpublications/er/pme/populationandmigrationestimatesapril2014/\#.VPjV_HzF-], [http://www.cso.ielen/releasesandpublications/er/rpp/regionalpopulationprojections2016-2031/\#.VK6p48n2QqE], retrieved on 11 March 2015.

51. All long-term planning exercises have intrinsic limitations. For instance, the ESRI considered that oil price would be around 100 USD per barrel in the period, while it is currently priced at -60 USD, so we took the liberty to make some shortcuts so as not to overcomplexify the analyses. GNP growth rates are applied to GNP figures, assuming that population growth rate will not differ significantly between Ireland and EU core countries. GNP growth rates for 2019 and 2020 are not given by the ESRI for the delayed recovery scenario, so they are assumed to be the same as for 2018. GNP growth rate for EU core countries is assumed to be the same as GDP EU 15 growth rate. 


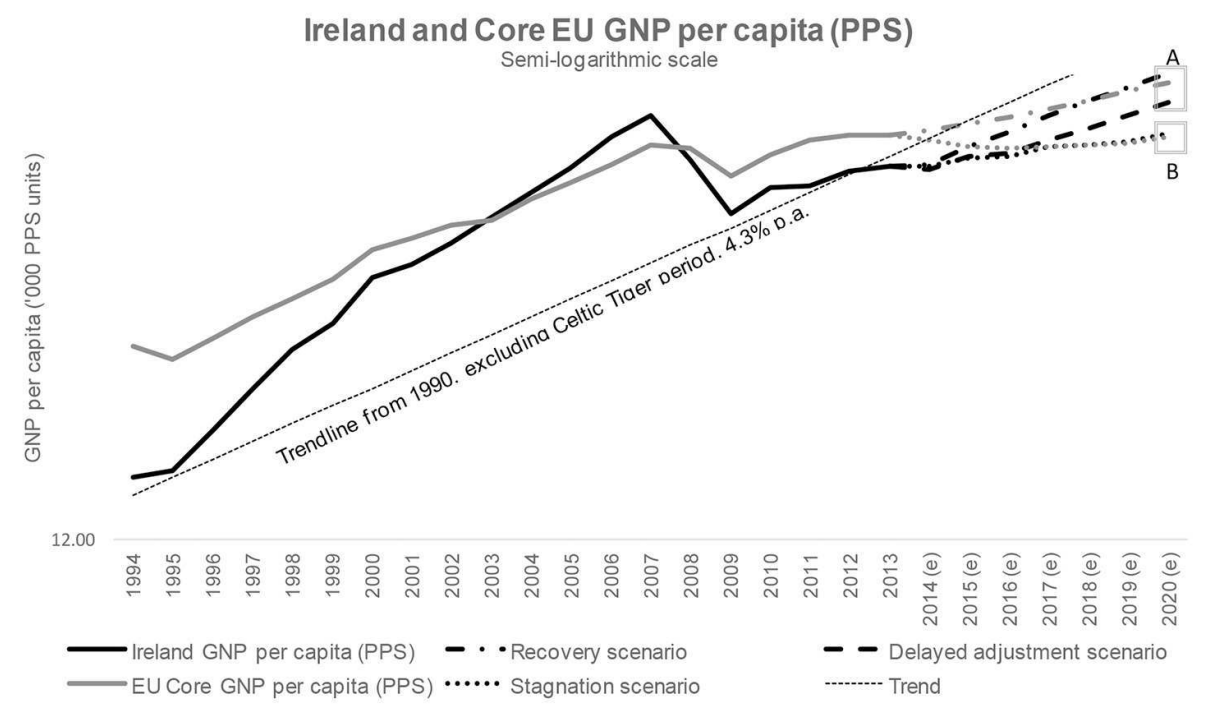

Figure 2: GNP per capita (PPS) - Ireland and Core EU Countries with projections by the ESRI for 20142020 (Eurostat, AMECO, op.cit. \& John FitzGerald and Ide Kearney [eds], op. cit.)

since corrected by the crisis. Thus the crisis could be seen as a harsh regulator of the Irish economic development. Having veered off its traditional position, Ireland was hit more than its neighbours to finally return to a path similar to that of the EU core countries.

To conclude, the crisis stopped or paused 15 years of exceptional Irish growth. It cancelled out the excesses of the Celtic Tiger and revealed the weaknesses of the development model policies. Now that the worst years of the crisis are probably behind us, the question is whether the Celtic Tiger is going to be able to roar again. The development model on which Ireland has based its development model for the last 60 years is clearly running out of fuel as many of the competitive advantages that Ireland could boast in the early 1990s have disappeared one after the other. Ireland is no longer a peripheral developing economy but a developed one, economically close to the EU core countries. Nonetheless, so far Ireland has managed to preserve its most important competitive advantage to carry on attracting FDI: its tax system. But how long will it take for the EU and possibly the US ${ }^{52}$ to force Ireland to stop undercutting them thanks to its fiscal policy. Moreover two new threats are looming. The first one is the UK's possible

52. In 2013, US Congress investigated the use of Irish companies by Apple to avoid paying taxes in the US. In 2014, Barack Obama singled out Ireland for criticism. In 2015, US Congress introduced a bill to curb corporate tax inversions. Simon Carswell, "Ending Double Irish' should be start of tax changes - US lawmaker", The Irish Times, 21 January 2015. 
exit from the EU. If the UK leaves the EU, tariffs will have to be collected on British exports entering the Republic. Therefore, both countries will be hit as they have integrated economies. Secondly, the European Union and the United States are trying to secure a Transatlantic Trade and Investment Partnership (TTIP). The aim is to create a virtually single market between the US and the EU. Full studies of the impact of the TTIP in Ireland have not been published yet and most observers and proponents of the TTIP tend to take an overall view: what is good for the EU as a whole is necessarily good for Ireland. Unfortunately, if Ireland has benefited from previous European developments so far, it does not mean that it will always be the case. The problem for Ireland is that the TTIP is likely to break the status quo and give US firms direct access to the European Union, which may rapidly undermine Ireland's position as an easy entry point into the EU market. This is even truer given the importance of the chemical and pharmaceutical industries in Ireland ( $58 \%$ of Irish exports) $)^{53}$, most of which FDI-backed, very protected against US exports ${ }^{54}$ and focused by TTIP.

There is no obvious "new development" model for Ireland, but the country will have to learn how to promote its competitive advantage with investors, despite its position as a near-core EU country (from a GNP per capita point of view). The country will also have to build a new model for its society, since it can no longer hope to receive a windfall similar to the one of the Celtic Tiger years.

53. "Irish goods export performance in 2013 back to 2008 level", Finfacts Website, (retrieved on 10 October 2014).

54. "The second key industry in this regard is the chemical and pharmaceutical industry (including cosmetics). In this sector, the barriers to US exports to the EU are between $15 \%$ and $35 \%$, depending on the sub-sector, and between $9 \%$ and $15 \%$ in the other direction. In particular, the divergent regulation of chemicals (REACH in the EU and the Toxic Substances Control Act in the US) have increased rather than reduced the barriers". Klaus Günter Deutsch, "Atlantic unity in global competition”, Deutsche Bank Research, EU Monitor, 19 August 2013. [http://www.dbresearch.com/PROD/DBR_INTERNET_EN-PROD/PROD0000000000318466/Atl antic+unity+in+global+competition\%3A+T-TIP+in+perspective.PDF], retrieved on 10 October 2014. 